\title{
JOHNSON AND LONDON: \\ IN SEARCH OF A CITY'S CIVILITY
}

\author{
BY THOMAS M. CURLEY
}

Mr. Curley teaches English at Bridgewater State College, Massachusetts

$\mathrm{L}^{\mathrm{on}}$ NDON certainly had a special fascination for eighteenth-century English writers. Its unprecedented growth in population, size, wealth, and prestige made the city an international capital of commerce and politics and a recurring, if ambiguous, symbol of British civilization in literature. To Addison, Defoe, Boswell, and Gibbon, the metropolis had become an imperial "emporium for the whole earth" without a rival in its plenum of power, pleasures, and opportunities "except old Rome in Trajan's time." Others, however, expressed mixed feelings or positive hostility for a place associated with poverty as well as fame in their lives. The works of Fielding, Richardson, Pope, and Blake present a diabolical Vanity Fair of sin, disease, hunger, crime, filth, and in justice. Here Hogarth graphically depicted the terrifying symptoms of our modern urban ills, and here Burke eloquently located the last citadel of a vanishing Christian-classical heritage. Probably no man of the century was more concerned with the question of the city's positive and negative influence upon the quality of civilization than Samuel Johnson. To study his writings is to discover a complex and representative response to London that combined a lifelong respect for the traditional rural values of the British countryside with a growing admiration of his modern industrial society. His interest in London permeates his literary canon and involved an enlightened investigation of savage and civilized ways of life that eventually motivated his celebrated tour of Scotland for proof of the superiority of his urban English culture.

Unfortunately, posterity has dealt unfairly with Johnson's attitude

\footnotetext{
I The substance of this article was originally presented in a paper, "Johnson and London: In Search of a City's Civility," delivered at the seminar on Eighteenth-Century Interdisciplinary Studies in the 1976 conference of the Northeast Modern Language Association. For the equation of London with Trajan's Rome, see Daniel Defoe, $A$ Tour through the Whole Island of Great Britain, ed. Pat Rogers (Baltimore: Penguin Books, $197 \mathrm{r}$ ), p. 286. For suggestive studies of Johnson's London, see Thomas Babington Macaulay, History of England (Boston: Houghton Miflin, 1900), 2:69-I I5; J. H. Plumb, England in the Eighteenth Century (Middlesex, England: Pelican, 195 I); Donald Greene, The Age of Exuberance (New York: Random House, 1970); and Thomas M. Curley, Samuel Johnson and the Age of Travel (to be published by the University of Georgia Press).
} 
toward the city. His famous love of London was neither blind nor unqualified nor, in fact, easily acquired during his struggling years in Grubstreet. When in 1737 Johnson left his birthplace of Lichfield, his initial exposure to the city was harrowing enough to reappear as a major literary theme in his poetry and prose thereafter. Few details have survived of what was to become the most characteristic plot of his fiction, except to confirm that Johnson's arrival at London resulted in poverty, failure, and a speedy return home without a job or a producer for his play, Irene. In his later essay tales the majority of his protagonists suffer this sad initiation into life as they re-enact a veritable Paradise Lost from happy rural innocence into disillusioning urban experience that sends them home with career ambitions defeated. They are a frustrated group of provincial pupils, poets, and chambermaids enduring corruption and defeat in a cruel city that afterwards left Johnson himself always feeling like a storm-tossed sailor in "the wild of life." The abortive hopes of such urban adventurers as Gelalledin (Idler 75), Eumathes' pupil (Ramblers I32, I 95, and 196), Polyphilus (Rambler 19), Liberalis (Rambler 163), Eubulus (Ramblers 26 and 27), Misargyrus (Adventurers 34, 4I, and 62), Misella (Ramblers I 70 and I 7I), Zosima (Rambler I 2), Betty Broom (Idlers 26 and 29), and the hero of Rasselas all seem to emanate from Johnson's troubled memory of his many difficulties in London. His close friend, Hesther Thrale, heard him later confess to an autobiographical impulse behind the production of one of these tales: "he had his own outset into life in his eye when he wrote the eastern story of Gelaleddin." As if exorcising the recollection, he kept telling the same sad story of youthful disappointments in his fiction. No doubt, his notorious fondness for London was actually a bitter-sweet affair, mingling the pain of early rejection and the pleasure of later acclaim in the bustling social life of the city.

The pessimistic plot typical of Johnson's fiction reflected not only personal experience but also an industrial revolution which was luring so many rustics to London that contemporaries feared for the depopulation of the countryside. Numerous authors were, like Johnson, originally provincials ambitious to make their fortunes in London and prepared to adopt metropolitan standards. These were the men most obsessed with transforming their urban trials into favorite

\footnotetext{
${ }^{2}$ Hester Lynch Piozzi, Anecdotes of the late Dr. Samuel Johnson (Cambridge, Mass.: Harvard University Press, 1932), p. 34. For the popularity of this theme in the eighteenth century, see especially Paul Fussell, The Rhetorical World of Augustan Humanism (Oxford: Clarendon Press, I965), chapters 8 and II.
} 
literary themes. Swift in Gulliver's Travels, Goldsmith in the Citizen of the World, Fielding in Tom Jones, and Smollett in Roderick Random comprise a notable few of the many writers preoccupied with travel into and out of a corrupt city as a vehicle of mental and moral discovery. ${ }^{3}$ Not surprisingly, Johnson's first major publication exploits this conventional theme in a summary manner typical of most literary diatribes against the city. Written in 1738 , his poem London adapts Juvenal's attack on ancient Rome in Satire III to criticize a modern urban sewer of foreign nationalities, immorality, atheism, poverty, lawlessness, and greed:

London! the needy villain's gen'ral home,

The common shore of Paris and of Rome;

With eager thirst, by folly or by fate,

Sucks in the dregs of each corrupted state.

Far from being a source of civilization, London is portrayed as an inhuman chaos of vices eroding traditional British virtues and crushing an individual's noblest aspirations through the collective savagery of a selfish society.

The author of London is still the loyal son of Lichfield who prefers the wholesome simplicity of country living in remote Wales, Scotland, Ireland, or even the newly established American colony of Georgia to the corrupting luxuries of the cold metropolis. A1though his appeal for a return to simple rural goodness is communicated in the sophisticated genre of a poetic imitation written for a civilized audience educated in the classics, his rejection of the decadent civilized values represented by London is totally sincere and very powerful. Compared to Juvenal, Johnson expresses greater outrage over the city's ruthless money ethic and far more sympathy with the classical ideal of pastoral retirement. ${ }^{4}$ There is something of an Elizabethan's abhorrence of social and moral chaos in London, an explosive patriotic hatred of a degenerate modern society that has betrayed a sturdy British heritage descending from the glorious reigns of Elizabeth, Alfred, Henry V, and Edward III:

\footnotetext{
${ }^{3}$ For one contemporary report on the depopulation of rural areas, see Arthur Young, The Farmer's Letters to the People of England (1767). Oliver Goldsmith's The Deserted Village is the best known expression of this economic problem, which may have been overly exaggerated. See H. L. Beales, "Travels and Communications," in Johnson's England, ed. A. S. Turberville (Oxford: Clarendon Press, I 933), I:125 ff.

4 Juvenal represents the flight to the Italian countryside as an unsavory but unavoidable option to preserve one's integrity. Johnson, by contrast, views rural retirement with a genuine nostalgic approval.
} 
Illustrious Edward! from the realms of day,

The land of heroes and of saints survey;

Nor hope the British lineaments to trace,

The rustick grandeur, or the surly grace,

But lost in thoughtless ease, and empty show,

Behold the warrior dwindled to a beau;

Sense, freedom, piety refin'd away

Of France the mimick, and of Spain the prey.

None of Johnson's works ever surpassed London in the severity of its indictment of urban corruption. However, even in this poem there is evidence that the city was already casting its spell upon him. For unlike Juvenal, Johnson concluded his poem with a promise to return and reform the degenerate state of the metropolis. In his life and literature, the city would ever after remain his true home and the focal point of his inquiries into the possibilities and limitations of an urban environment in fully realizing man's purpose for being. That he was sensitive to the drawbacks should be obvious. He lived in the slums and was robbed in the streets, endured loneliness and neglect for more than a decade, saw the daily tragedies of the sick and the needy, and memorialized these experiences in his mature writings. Where else is there a more compelling case history of Grubstreet squalor and failure than his Life of Savage ( 1744)? What can better convey his acute sense of London's miseries and temptations than his equation of the city with hell and his association of urban poverty, prostitution, wife-hunting, indolence, and imprisonment with the tortures of the damned throughout the Ramblers ( $1750-1752$ ) and the Idlers ( $1758-1760$ )? How can we more readily discover his reservations about the city's potential for producing happiness than to review his microcosm of human follies and frustrations in the Cairo of Rasselas (1759)? Even during the monumental task of civilizing the English Language in the Dictionary (1755), he complained about the corrupt tendency of his urban civilization to produce chaotic linguistic innovations: "But no such constancy can be expected in a people polished by arts, and classed by subordination, where one part of the community is sustained and accommodated by the labour of the other."

In his economic views he ever remained a staunch agrarian who

${ }^{5}$ Samuel Johnson, The Works of Samuel Johnson, L.L.D. (New York: George Dearborn, 1837 ), 2:453. Hereafter cited as Works. 
gave priority to agriculture over commerce in generating national prosperity, self-sufficiency, and moral health. Published in I 756, his Some Thoughts on Agriculture clearly favors the farmer over the London "cit" in the moral hierarchy of England's social classes: "Luxury, avarice, injustice, violence, ambition, take up their ordinary residence in populous cities; while the hard and labourious life of the husbandman will not admit of these vices. The honest farmer lives in a wise and happy state, which inclines him to justice, temperance, sobriety, sincerity, and every virtue that can dignify human nature." The fact that Johnson had previously spent twenty struggling years in London away from Lichfield may help to explain this unusually glowing tribute to rural values. He praised agriculture for supplying the economic necessities, without which commerce and social improvements were impossible. But in other writings he was more strongly affirming that man required more than the satisfaction of his bodily necessities to fully realize his humanity. To be sure, the virtues of simplicity, stability, and self-sufficiency which he associated with agriculture would always appeal to his conservative temperament. Because he felt the vexations of excessive civilization, he annually escaped from London to Lichfield in later life and could consider his birthplace an ideal social mean between the extremes of barbarity and an overly luxurious society. This attitude is implicit in a humorous conversation about his Scottish biographer, Boswell, with that notorious city-bred rake and political agitator, John Wilkes, in I 776: "I turned him loose at Lichfield, my native city, that he might see for once real civility: for you know he lives among savages in Scotland, and among rakes in London." However, for all his appreciation of rural life, Johnson recognized the superior importance of a highly developed commercial society in promoting human happiness and social progress.

$\mathrm{He}$ is, after all, probably best remembered for declaring that "when a man is tired of London, he is tired of life; for there is in London all that life can afford." However hackneyed these words may now seem, his statement does isolate his chief reason for favoring an urban society despite its dangers and trials. The English countryside might have been rich in soil and homely virtues, but John-

\footnotetext{
${ }^{6}$ Works, $2: 534$.

${ }^{7}$ James Boswell, Boswell's Life of Johnson, ed. G. B. Hill and L. F. Powell (Oxford: Clarendon Press, I934-1950), 3:77. Hereafter cited as Life.

${ }^{8}$ Life, $3: 178$.
} 
son ultimately criticized the country for boring and brutalizing humanity in his writings. ${ }^{9}$ To dwell among the untrodden ways of pastoral Britain was to truly risk growing tired of life and succumbing to the great Johnsonian sin of idleness. Even worse, the more primitive areas of the globe offered only the barest human necessities for sustaining, without improving, human life. Fundamental moral principles accounted for his well-known abhorrence of the wilderness. The privations of a rural habitat inhibited mental and moral growth, obstructed social mobility, and could frustrate the spiritual ends for which God created man. In his view all societies evolved through successive stages of destitution, convenience, and luxury: "The regular progress of cultivated life is from Necessaries to Accommodations, from Accommodations to Ornaments."10 However, the middle state of economic convenience best served the highest human needs of virtue and religion. Such a state preserved the positive contributions of rural simplicity and urban civilization without lapsing into the deficiences of barbarism and the corruptions of excessive refinement.

Johnson conceived the ideal society as a constructive resolution of opposite tendencies in human development, between animal savagery and enervating decadence, both of which debased the spirit of man. His conception reflects a characteristic desire in his thinking for a happy via media of moderation, sufficiency, and harmony that allies his views to the traditional Renaissance vision of balance in politics, religion, ethics, and art. Nihil in excessu. When in his century primitivists arose in increasing numbers to laud the noble savage, he naturally attacked their romantic dreams of a blissful state of nature as early as his Life of Drake (I 740): "Among savage nations, imaginary wants find indeed no place; but their strength is exhausted by necessary toils, and their passions agitated not by contests about superiority, affluence, or precedence, but by perpetual care for the present day, and by fear of perishing for want of food.... The question is not, Whether a good Indian or bad Englishman be most happy? but, Which state is most desirable, supposing virtue

\footnotetext{
9 The attack against rural boredom and the growing vogue of primitivism began in his biographies of Drake and Savage in the 17405 , continued in his moral essays (Ramblers 42 and 46,$142 ;$ Adventurers 102, 126; Idlers 16, 71), and climaxed in Rasselas, chapter 19.

${ }^{10}$ Samuel Johnson, Dedication for Sir Joshua Reynolds's Seven Discourses (1778), Samuel Johnson's Prefaces and Dedications, ed. Allen Hazen (New Haven: Yale University Press, I 937), p. 197.
} 
and reason the same in both?"11 And the answer for Johnson was that civilized society most effectually cultivated the full rational and spiritual potential of mankind. London was certainly no exemplar of the ideal Johnsonian via media in economic development since the city too often exhibited the vices of luxury destroying the moral balance of the perfect society. Perhaps, as so many of his writings emphasize, utopia could never exist in this inherently imperfect world. But London offered exciting possibilities for improvement and remained the great European dynamo of power, wealth, learning, and industry activating and absorbing the energies of human beings in their pursuit of personal betterment and social progress: "To receive and to communicate assistance, constitutes the happiness of human life: man may indeed preserve his existence in solitude, but can enjoy it only in society: . . . he gains leisure for intellectual pleasures, and enjoys the happiness of reason and reflection" (Adventurer 67).

Johnson's very philosophy of man is decidedly urban in orientation. Alone man is regarded as limited and weak, wounded by sin and motivated by self-interest. But he is also a naturally active and social being, capable of being led by the dictates of reason and revelation to transform egotism into a love of others and join in the common search for happiness here and in the hereafter. His explanation of the formation and continuation of society was based on a Christian faith in the power of love to subdue human pride and other vicious traits inimicable to civic cooperation, a Mandevillian sense of the merging of mankind's competing self-interests and instincts for self-preservation in an industrious society for the common good, and a Lockean assumption of an original rational choice of a community of personal rights and public responsibilities as the best environment for individual survival and mutual improvement. Johnson's Sermon I fully expounds his philosophy of civilization after noting that only God is perfectly self-sufficient:

Every man perceives his own insufficiency to supply himself with what either necessity or convenience require, and applies to others for assistance. Every one feels his satisfaction impaired by the suppression of pleasing emotions, and consequently endeavours to find an opportunity of diffusing his satisfaction. As a general relation to the rest of the species, is not sufficient to procure gratifications for the private desires of particular persons; as closer ties of union are necessary to promote the separate interests of individ-

11 Works, 2:333, 336 . 
uals, the great society of the world is divided into different communities ... and more contracted associations, which pursue, or ought to pursue, a particular interest, in subordination to the publick good, and consistently with the general happiness of mankind. ${ }^{12}$

The passage succinctly summarizes his theory of social organization and appropriately prefaces a defense of marriage, the most basic social unit.

Civilization, as the Latin root of the word implies, meant the city; the city was the site and symbol of human cooperation which produced all those improvements that made life a little less unhappy, extended knowledge, and clarified man's spiritual destiny. Johnson acknowledged this derivation in his Dictionary and illustrated the multiple shades of meaning in the word civil by numerous quotations which, taken together, comprehend his complex concept of civilization. His choice of illustrative passages from the works of Richard Hooker, Thomas Sprat, Jeremy Taylor, Lord Roscommon, Edmund Spenser, William Shakespeare, John Milton, and other authorities of the English language is illuminating. The quotations suggest that to Johnson civilization is divinely inspired but extremely frail, requires personal integrity and the public rule of law for its preservation, fades whenever man's penchant for war and wickedness predominates, encourages polished manners and virtuous conduct, nourishes the arts and sciences, and now exists in England in a state comparable to the greatness of the Roman Empire after its emergence from the savagery of internecine civil wars. Because civilization is such a precious commodity, Johnson devoted much of his moral writing to inculcating those qualities of mind and character necessary for its maintenance and growth. Whatever violated an individual's appointed role as a useful and dynamic member of society-be it indolence, dishonesty, profligacy, or eccentricityis castigated in Johnson's morality. Conversely, the civic virtues of charity, benevolence, industriousness, inquisitiveness, and integrity normally received his highest praise. ${ }^{13}$

London might have been the hell that Johnson, Fielding, and Smollett all described, but all their protagonists were obliged to

12 Samuel Johnson, Sermon I, The Works of Samuel Johnson (Oxford, 1825), 9:290. ${ }^{13}$ For two excellent books on Johnson's morality, read Walter Jackson Bate, The Achievement of Samuel Johnson (New York: Oxford University Press, 1955) and Paul Alkon, Samuel Johnson and Moral Discipline (Evanston, Illinois: Northwestern University Press, 1967). 
see it for themselves to attain maturity and learn the spiritual wisdom of higher goals than this world could satisfy: "To know the world is necessary, since we were born for the help of one another; and to know it early is convenient if it be only that we may learn early to despise it" (Idler 80). The city was an indispensable, if dangerous, catalyst of human growth and cultural development that distinguished man from the beast. Johnson proudly pointed to London as the seat of the British Empire and its world trade, where all "learning and science" and all pleasures and professions converged. ${ }^{14}$ Here various organizations, ranging from the British Museum to his own famous Literary Club, proliferated in the eighteenth century to advance the arts and sciences. Moreover, London's dense population and rising middle class virtually accounted for many remarkable historical developments of his age. He recognized with some disapproval the crucial influence of a thriving urban society upon such democratic tendencies as the spread of literacy, the emergence of journalism to replace the patronage system, and the popularity of the novel, magazine, travel book, and other literary forms which reflected the tastes of a mass audience: "The present age, if we consider chiefly the state of our own country, may be stiled with great propriety The Age of Authors, for, perhaps, there never was a time, in which men of all degrees of ability, of every kind of education, of every profession and employment, were posting with ardour so general to the press" (Adventurer I 15 ). The energetic individualism fostered in London had generated so many diverse economic opportunities and social diversions that life in the city became more complex and, therefore, more attractive to use for the subject matter of fiction. ${ }^{15}$ Johnson also attributed the prevalence of charitable institutions and other benevolent organizations partly to the practical urban impulse to help all citizens become productive members of the community: "The prosperity of a people is proportionate to the number of hands and minds usefully employed. To the community sedition is a fever, corruption is a gangrene, and idleness an atrophy" (Idler 22). He considered charity the supreme virtue of a

14 Life, 3:378. See also Life, I:44 I ; $2: 120$; and $3: 253$.

${ }^{15}$ Such essays as Adventurer II 5 and Idlers $7,30,84$, and 85 relate popular literary forms to the urban audience and sometimes lament the growing mediocrity of intellectual standards. Ramblers $9,58,73$, and I 3 I express an enthusiasm for the city and a utilitarian respect for the pursuit of urban riches. For a seminal study of the relationship between sociological factors and prose fiction, consult Ian Watt, The Rise of the Novel (Berkeley: University of California Press, 1965). 
civilized Christian society, and London was beginning to manifest this peerless quality as never before in its long history.

There were clearly sound reasons for his growing admiration of London even if he had never traveled to the Hebrides for positive proof of the superiority of his civilized urban society. Yet, despite his reputation as the parochial John Bull of English literature, he was always eager to base his enthusiasm for the city on a cosmopolitan knowledge of the human condition everywhere around the globe. Perhaps the favorite intellectual procedure advocated and practiced by him was a comparative study of nations and individuals for a proper assessment of one's own moral and social state. In his writings and conversations, he characteristically accentuated London's advantages by noting less fortunate places like Dublin, Wales, Iceland, Minorca, and even Paris and Peking. His most thoughtful panegyric on city life, Adventurer 67, was published in 1753 and especially recommended a comparative study of savage and civilized regions in a passage prophetic of his intellectual achievement on the Highland tour twenty years later: "Happiness is enjoyed only . . . by experience of its contrary: we who have long lived amidst the conveniences of a town immensely populous, have scarce an idea of a place where desire cannot be gratified by money. In order to have a just sense of this artificial plenty, it is necessary to have passed some time in a distant colony, or those parts of our island which are thinly inhabited." What was a theoretical necessity in a moral essay defending the city became a practical course of action in 1773 on his trip to that bleak and lonely outpost of Great Britain, the Western Islands of Scotland.

Adventurer 67 demands a careful examination because its assumptions and conclusions constituted the underlying purpose of his later survey of the Hebrides. Johnson opened this essay with a telling epigraph from Vergil's Aeneid, Inventas-vitam excoluere per artes, to express his Roman faith in the epic significance of civilization and to suggest an equivalent stage of social development between the present British Empire and the ancient Roman Empire. He then proceeds to describe with pride and delight the commercial energy and incredible extent of London as well as the diversity and quality of its goods and occupations, all of which effortlessly supply the necessities and luxuries of life, work against poverty and idleness by encouraging industry and social mobility, and foster a benevolent sense of interdependence necessary for all cultural im- 
provements. However, although his paean to his modern Rome affirms that man's highest faculties are stimulated only in society, he does concede the excellence of the noble savage's ingenuity and dexterity. This essay may reiterate the sentiments favoring society in the earlier Life of Drake ( 1740 ), but there is now present a new nostalgic sense that civilized man has lost some valuable primitive instincts and skills well worth investigating in the backward areas of the globe: "It were a speculation worthy of a philosophical mind, to examine how much is taken away from our innate abilities, as well as added to them by artificial expedients. We are so accustomed to give and receive assistance, that each of us singly can do little for himself. . . But a survey of the various nations that inhabit the earth will inform us, that life may be supported with less assistance, and the dexterity, which practice enforced by necessity produces, is able to effect much by very scanty means." The passage enunciates a seminal and fundamental anthropological concern which culminated in his investigation of primitive Highland customs and in his increased appreciation of urban refinements after the tour.

Allied with this anthropological interest in savage cultures was an equally strong preoccupation with the history and geography of European nations important to the formation of British civilization. All his life he was an avid fan of antiquarian studies and travel literature dealing especially with the northern countries surrounding his beloved England. He closely attended to descriptions of Scandinavian and Arctic races and legends for information about the root drives and desires of primitive human nature that had directly shaped European civilization and British law. This little known fascination with northern antiquities continued throughout his career and made him particularly curious about the ancient history of the British isles and current explorations of Iceland, Greenland, Norway, Sweden, Denmark, Siberia, and the North Pole. The barren regions to the north best preserved a "pure" state of nature illuminating man's innate abilities and earliest institutions and underscoring the benefits of a modern urban way of life. They helped him to better comprehend the origins of his own culture and more accurately assess the present state of England, its body of laws, and its national religious heritage. As he wrote in the Dedication for Thomas Percy's Reliques of English Poetry ( 1765 ), "No active or comprehensive mind can forbear some attention to the reliques of antiquity. It is prompted by a natural curiosity to survey the progress of life 
and manners and to inquire by what gradations barbarity was civilized, grossness refined, and ignorance instructed." ${ }^{16}$ Already in 1742 when advertising a catalog of books in the Harleian Library, he singled out the historical volumes on northern Europe for possessing greater relevance to Englishmen than even the venerated classics: "they ought not to be neglected by those that owe to the men whose memories they preserve, their constitution, their properties, and their liberties."17 Not only had he researched the subject of northern antiquities intensively for legal and lexicographical writings, but he also planned a voyage to Iceland twice in the I750s to carry out a comparative study of civilized and savage states. ${ }^{18}$ However, the more accessible Hebrides would be the Ultima Thule, the northernmost frontier for Johnson to personally examine savage customs and forcefully understand why the cultural conveniences of London society best served the most important human needs.

His travel book, A Journey to the Western Islands of Scotland ( 1775 ), is unique among his works for documenting the intellectual process of a great thinker coming to grips with an unknown moral environment and forming conclusions about mankind from the immediate data of his Highland experience. From the outset Johnson portrayed himself as an insular city-dweller intent on conducting an empirical and inductive study of an ancient and impoverished Celtic race in need of the prosperity of English civilization. The arresting juxtaposition of a sophisticated urban observer and a remote rural landscape cast the whole question of city versus country life in sharp relief and lends a universal significance to the answers discovered on the tour. A civilized Londoner embodying the best metropolitan values traverses the Hebrides for a representative glimpse of all the world's preponderant wilderness: "Regions

\footnotetext{
${ }^{16}$ Samuel Johnson, Dedication for Thomas Percy's Reliques of ancient English Poetry, Samuel Johnson's Prefaces and Dedications, p. I67.

17 Works, $2: 494$.

${ }^{18}$ For his plans to explore Iceland, see Life, $1: 242$ and The Letters of Samuel Johnson, ed. R. W. Chapman (Oxford: Clarendon Press, 1952), no. II 58 . His special fascination with the history and language of northern Europe is evinced in all the prefatory writings of his English Dictionary, his edition of Shakespeare, and his valuable contributions to Robert Chambers's Vinerian Law Lectures, 1766-1767. See E. L. McAdam, Jr., Dr. Johnson and the English Law (Syracuse: Syracuse University Press, 1951). Johnson was widely read in books on northern antiquities and British history, ranging from Camden's Remains to George Hickes's Linguarum Vett. Septentrionalium Thesaurus. Not only had he read more than a dozen geographical descriptions of Scotland and Ireland, but he also kept abreast of Arctic and Scandinavian geography in travel books by Thomas James, Hans Egede, David Cranz, Niels Horrebov, Eric Pontopiddan, John Perry, Constantine Phipps, Henry Ellis, Maupertuis, and many more explorers.
} 
mountainous and wild, thinly inhabited, and little cultivated, make a great part of the earth, and he that has never seen them, must live unacquainted with much of the face of nature, and with one of the great scenes of human existence."19 Early in the narrative the cumulative spectacle of afforestation at Aberbrothick, terrifying ocean cliffs at Buchan, and barren "naked nature" on the road to Sky made an indelible impression, which, by his own admission, inspired him to write the travel book and ponder the plight of a once proud people forced by a vindictive English government to forsake their feudal way of life after the Highland uprising of $\mathrm{I} 745$. He had never before seen scenery so wild as the forbidding glens and gloomy lochs of the Highlands, and his response to the topography was a mixture of rapt fascination and Elizabethan horror of cosmic chaos: "An eye accustomed to flowery pastures and waving harvests is astonished and repelled by this wide extent of hopeless sterility. The appearance is that of matter incapable of form or usefulness, dismissed by nature from her care and disinherited of her favours, left in its original elemental state, or quickened only with one sullen power of useless vegetation" (pp. 39-40). His examination of the countryside was a fitting prelude to his chief topic of interest, the Highlanders themselves.

The rugged habitat helped to explain the hardy national character of the inhabitants as the travelers turned from factual observations to moral generalizations about the customs of the clans. The harsh environment shaped and reflected a savage people who were woefully poor, ignorant, lawless, and warlike and yet possessed an admirable bravery, simplicity, hospitality, and patriarchal loyalty. Johnson was coming face to face with those primitive qualities of character which had so intrigued him in his earlier writings and had won his respect whenever he considered the gains and losses of England's attainment of perhaps an overly refined civilization. In accordance with his lifelong interest in northern anthropology and antiquities, he constantly compared the Highlanders to the natives of the Arctic, Scandinavia, Russia, and ancient Germany to elucidate the ancient state of Britain and the modern state of Scotland from a wider historical and geographical perspective. What he wrote of the Highland economy is typical of his method of forming tentative

\footnotetext{
${ }^{10}$ Samuel Johnson, A Journey to the Western Islands of Scotland, ed. Mary Lascelles (New Haven: Yale University Press, 1971), 9:40. All future references to the Journey are to this standard edition of the text.
} 
conclusions by considering the habits of neighboring northern nations: "The petty tenants, and labouring peasants, live in miserable cabins, which afford them little more than shelter from the storms. The boor of Norway is said to make all his own utensils. In the Hebrides, whatever might be their ingenuity, the want of wood leaves them no materials. They are probably content with such accommodations as stones of different forms and sizes can afford them" (p. IOI). Repeated exposure to the kind and courageous Highlanders proved to be a valuable peripatetic education in appreciating, without exaggerating, the virtues of clan community and imaginatively empathizing with the primitive northern world of antiquity that had given birth to Great Britain during the obscure eras of Celtic and Anglo-Saxon rule.

As a consequence of his growing respect for the natives, his economic considerations would hang fire between the positive and negative consequences of introducing radical English reforms into the Highlands and destroying the ancient traditions of the clans. The hardy self-sufficiency and simple goodness found in Scotland strongly appealed to a conservative moralist like Johnson. But his eyewitness investigation of the impoverished Hebrides had convincingly demonstrated the dire need of importing an urban standard of living into a region missing not only the luxuries and even the social conveniences abounding in London but also many crucial agricultural and commercial necessities that made human life tolerable and cultural improvements possible: "But neither philosophical curiosity, nor commercial industry, have yet fixed their abode here, where the importunity of immediate want supplied but for the day, and craving on the morrow, has left little room for excursive knowledge or the pleasing fancies of distant profit" (p. 8I). Constantly Johnson pointed out the absence of cities or even substantial towns to underline the physical and cultural sterility of the Western Isles. London implicitly provided him with his economic standard of measurement, and not even the possession of primitive virtues and skills formerly praised in Adventurer 67 and now vividly witnessed on the tour could compensate for the privations of these backward people: "To a man that ranges the streets of London, where he is tempted to contrive wants for the pleasure of supplying them, a shop affords no image worthy of attention; but in an island, it turns the balance of existence between good and evil. To live in perpetual want of little things, is a state not indeed of torture, but 
of constant vexation" (p. I 3o). So Johnson wrote of the remote isle of Coll, and Coll he considered more prosperous than other places lacking even a humble shop to sweeten existence.

Early in the travel book upon his arrival at the capital of the Highlands in Inverness, he had commented favorably on the role of the Roman Empire in taming the barbari of its colonies. Thereafter the almost unrelieved sight of poverty and the alarming rumors of widespread emigration only convinced him of the pressing importance of reviving this constructive Roman spirit to alleviate the economic problems threatening to completely eradicate valuable clan traditions and severely depopulate the countryside. As he reluctantly came to recognize, some economic innovations were clearly warranted to raise the substandard existence of the Highlanders to a more civilized level that would preserve their heritage and yet prepare them to participate in the brave new world of modern commerce and agriculture. Thus, by the time that he reached Iona at the end of the journey, he appropriately defended civilization in the civilized intellectual act of recalling its ancient glory and contemplating its possible resurgence in Scotland. The ruined abbey of Iona had once housed the Irish missionaries responsible for spreading the principles of religion and law in pagan Scotland and England. Perhaps the seeds of British civilization would blossom again in the underdeveloped areas of Europe: "We now left those illustrious ruins, by which Mr. Boswell was much affected, nor would I willingly be thought to have looked upon them without some emotion. Perhaps, in the revolutions of the world, Iona may be sometime again the instructress of the Western Regions" ( $p$. I 53). Such is the noble, if troubled, hope for cultivating the Scottish wilderness that animates his elegiac travel book.

Unfortunately, prosperity would never come to the Hebrides. The tragic destiny of the ravaged Highlands would confirm the dark fears and gloomy presentiments pervading the Journey. Yet, for Johnson the trip remained an exhilarating opportunity to explore a wild state of nature, capture the spirit of Britain's ancient history, and affirm the superiority of his modern English culture: "All travel has its advantages. If the passenger visits better countries, he may learn to improve his own, and if fortune carries him to a worse, he may learn to enjoy it" (p. I38). Scotland was Johnson's ultimate testing-ground for weighing the good and the bad of opposite ways of life and earning the right to praise his own in London 
after glimpsing the primitive origins of his British civilization. Years of reflection had made him sensitive to the city's shortcomings. But in the end his eye-opening experience of the Hebrides removed any doubt that "the noblest prospect which a Scotchman ever sees, is the high road that leads him to London." ${ }^{20}$

${ }^{20}$ Life, $5: 387$. 